\title{
THE IMPACT OF ARTICLE 12 OF THE CONVENTION ON THE RIGHTS OF PERSONS WITH DISABILITIES ON QATAR'S PRIVATE LAW ${ }^{1}$
}

\author{
PATRICIA CUENCA GÓMEZ ${ }^{2}$ \\ MARÍA DEL CARMEN BARRANCO AVILÉS ${ }^{3}$ \\ MARIA LAURA SERRA ${ }^{4}$ \\ JAVIER ANSUÁTEGUI ROIG ${ }^{5}$ \\ PABLO RODRÍGUEZ DEL POZO ${ }^{6}$
}

\begin{abstract}
Article 12 of the Convention on the Rights of Persons with Disabilities provides that persons with disabilities are entitled to full legal capacity on an equal basis with others and obliges State Parties to provide access to the support that they may require exercising this legal capacity. This paper analyzes the main implications of this Article and its impact on Qatar's legal system, focusing on the general regulation of legal capacity and provisions in the domain of Private Law, including Family Law. We examine how Qatar's legislation needs to be adapted to the new paradigm of the CRPD, overcoming preconceptions based on the medical model and assistencialism, which is focused on protection, and moving towards the social model and the human rights approach, aimed at promoting the autonomy of persons with disabilities. To comply with Article 12, Qatar must review the legal provisions that allow the deprivation or restriction of legal capacity on the basis of disability and that require "be[ing] of sound of mind” as a condition to perform legal acts or to exercise rights. Qatar must also take action to replace regimes of substituted decision-making with supported decision-making - extending some support mechanisms available in current legislation - and to ensure the respect of the person's will and preferences.
\end{abstract}

Keywords: Disability, Legal Capacity, Private Law, Qatar, Convention on the Rights of Persons with Disabilities.

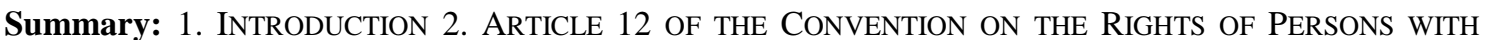
DisABILITIES 3. THE APPROACH TO LEGAL CAPACITY IN QATAR'S LEGAL SYSTEM 3.1. General framework on legal capacity in Qatar 3.2. Legal capacity to enter into a contract and to exercise civil rights 3.3. Legal capacity in Family Law 4. CERTAIN NECESSARY CHANGES

\footnotetext{
${ }^{1}$ This publication was made possible by the NPRP award NPRP-7-380-5-051 from the Qatar National Research Fund (a member of The Qatar Foundation). The statements made herein are solely the responsibility of the authors.

${ }^{2}$ Universidad Carlos III de Madrid, Spain (patricia.cuenca@uc3m.es).

${ }^{3}$ Universidad Carlos III de Madrid, Spain (mcarmen.barranco@uc3m.es).

${ }^{4}$ Universidad Carlos III de Madrid, Spain (marialaura.serra@nuigalway.ie).

${ }^{5}$ Universidad Carlos III de Madrid, Spain (javofil@der-pu.uc3m.es).

${ }^{6}$ Weill Cornell Medical College in Qatar (prd2002@qatar-med.cornell.edu).
} 


\section{INTRODUCTION}

Under the heading "Equal recognition before the law," Article 12 of the Convention on the Rights of Persons with Disabilities (hereinafter, CRPD) lays down a set of provisions that constitute a true revolution, challenging the traditional approach to legal capacity of persons with disabilities in domestic legal systems (Minkowitz, 20062007: 405-408 and Quinn, 2011). Article 12's revolutionary nature lies in the fact that it recognizes that all persons with disabilities should enjoy full legal capacity and have the right to exercise it on an equal basis with others. Consequently, it advocates moving from a model of substituted decision-making to a model of supported decision-making.

The purpose of this paper is to examine Qatar's legislation on legal capacity in the light of the requirements set out by Article 12 of the CRPD, as well as to point out certain changes that may be necessary to adequately implement this provision. Given the broad scope of this subject, our study will focus on the general framework applicable in Qatar, as well as on its implications for the regulation governing certain legal acts and specific rights in the Private Law domain.

\section{Article 12 of the Convention on the Rights of Persons with DisABILITIES}

The wording of Article 12 became one of the most controversial issues during the process of drafting the CRPD, and this provision was almost passed with a footnote, which following complex negotiations was finally removed. ${ }^{7}$ In any event, its removal did not prevent the fact that during the ratification and signing of the CRPD many reservations were expressed and interpretative declarations made about Article 12. According to certain experts, such reservations and declarations shall be null and void, since they are contrary to the purpose of the CRPD (International Disability Alliance, 2008).

The debate on the meaning and implications of Article 12 was not actually finalized. Therefore, the Committee on the Rights of Persons with Disabilities (hereinafter, the CRPD Committee) devoted its first General Comment (2014) to clarifying the meaning of the right to equal recognition before the law ${ }^{8}$. In the opinion of the CRPD Committee, the initial reports of the States Parties examined up to that point evidenced "a general misunderstanding of the exact scope of the obligations" under this article, as well as a "general failure to understand that the human rights-based model of disability implies a shift from the substitute decision-making paradigm to one that is based on supported decision-making."9

\footnotetext{
${ }^{7}$ On the debate about Article 12, see Palacios, 2008: 454-467 and Dhanda, 2006-2007: 438-456.

${ }^{8}$ On this General Comment see Arnstein-Kerslale and Flynn, 2016.

${ }^{9}$ De Bhailís and Flynn, 2017, aim to summarise the current understanding and literature around Article 12 of the CRPD. The volume 12, issue 1 of the International Journal of Law in Context, where this work was published, included a Special Issue on Legal Capacity and Human Rights.
} 
Below we will try to briefly examine the key elements of Article 12 and the innovations introduced thereby, moving away from the long-standing regulation of legal capacity. In any case, before going through its main aspects, it must be noted that this provision ultimately entails a paradigm shift in the philosophical approach to legal capacity (Quinn, 2010; Cuenca, 2011 and Cuenca, 2012a).

Historically speaking, legal capacity, and disability in general, has been tackled from an understanding rooted in the medical model and the perspective of assistencialism. As is generally known, the core principle of the medical model is to consider disability as a "problem" affecting a person, stemming from the individual deficiencies caused by a given impairment. Persons with disabilities are thus deemed as individuals that deviate from an allegedly standard pattern of behavior, and according to this approach the restrictions they suffer regarding their involvement in society are due to their deficiencies. From this standpoint, the approach to disability focuses on "standardizing," healing, or rehabilitating disabled persons in order to integrate them within society as well as on assisting individuals who are unable to achieve such integration (Palacios, 2008a; Oliver, 1996; and Barnes and Mercer, 2003).

From this point of view, it can be considered that cognitive deficits shown by certain persons with disabilities-mainly (although not only) persons with mental or psychosocial disabilities - prevent them from making their own decisions "correctly," i.e. autonomously, independently, freely, and responsibly. The foregoing implies, as a natural and essential consequence meant to ensure the protection of persons with disabilities who have difficulty in making decisions, that their legal capacity must be removed or restricted and that they must be replaced by a third person to make such decisions on their behalf and "in their best interests." Furthermore, departing from the traditional approach, legal capacity is dealt with as a technical issue from a private law perspective related to intervention in legal transactions (Quinn, 2009 and Bariffi, 2009). Its regulation also seeks to ensure the security of legal transactions and focuses on economic aspects. In any case, in many legal systems the legal incapacitation and/or the consideration that a person lacks the "standard" mental capacity does not only affect the economic sphere, but also the individual, social, and political domains, preventing persons with disabilities from exercising their fundamental rights. Therefore, deprivation of legal capacity means the civil death of persons with cognitive disabilities (Quinn, 2016).

The CRPD moves away from medical model to social model of disability. As opposed to the medical model, the social model is characterized by transferring the "problem" of disability from the individual to society as a whole. From this perspective, it is not individual limitations that give rise to disabilities, but rather the limitations of a society designed on the basis of a normalcy standard that leads to barriers excluding and discriminating against persons with disabilities (Palacios, 2008a). Thus, the approach to disability currently revolves around society's adaptation instead of around the individuals' rehabilitation. This view takes disability to the discrimination domain, and thus to the sphere of human rights. 
Regarding legal capacity, the social model departs from the premise that difficulties experienced by disabled persons regarding decision-making processes are not exclusively rooted in their personal deficiencies. In fact, it argues that they can stem from, and be worsened by, the design of the environment (including intellectual, communicational, or behavioral aspects). These axes allow us to conclude that legal capacity is not deemed as something natural, but as a social construct that has traditionally justified exclusion from the law (and from the human rights) of various groups, and which must be reconsidered in order to include persons with disabilities (Dhanda, 2003-2004 and Quinn, 2016).

Hence, the regulation of legal capacity as set forth in the CRPD focuses on removing barriers and adapting its exercise to the situation and needs of persons with disabilities (Cuenca, 2011: 237 y 238). It is central to this line of argument to ensure universal accessibility within the domains where legal capacity may be exercised ${ }^{10}$ through universal design, ${ }^{11}$ the adoption of accessibility measures, ${ }^{12}$ and the implementation of any reasonable accommodation that may be required, ${ }^{13}$ as well as to provide any support needed by persons with disabilities to enable them to make their own decisions.

In line with the adoption of the social model regarding the approach to legal capacity, the CRPD contends that assistencialism approach and the private law perspective must be replaced by the human rights-based approach. This shift has two closely-related implications.

\footnotetext{
${ }^{10}$ Universal accessibility is governed by Article 9 of the CRPD, which provides the following: "To enable persons with disabilities to live independently and participate fully in all aspects of life, States Parties shall take appropriate measures to ensure to persons with disabilities access, on an equal basis with others, to the physical environment, to transportation, to information and communications, including information and communications technologies and systems, and to other facilities and services open or provided to the public, both in urban and in rural areas.” The ties between this provision and Article 12 have been highlighted by the CRPD Committee (2014: para. 37) which points out that the "[l]ack of accessibility to information and communication and inaccessible services may constitute barriers to the realization of legal capacity for some persons with disabilities, in practice," On universal accessibility and the various strategies to implement it, see De Asís, 2013.

${ }^{11}$ From our perspective, universal design amounts to a general strategy adopted $a b$ initio, initially foreseeing a legal interest, product, or service to achieve universal accessibility. Article 2 of the CRPD defines the notion of "universal design" as "the design of products, environments, programmes and services to be usable by all people, to the greatest extent possible, without the need for adaptation or specialized design.”

${ }^{12}$ In our opinion, accessibility measures are also a general strategy meant to redesign all goods or services that initially were not universally accessible.

${ }^{13}$ Reasonable accommodation amounts to a specific strategy aimed at accomplishing universal accessibility. This notion is defined in Article 2 of the CRPD as "necessary and appropriate modification and adjustments not imposing a disproportionate or undue burden, where needed in a particular case, to ensure to persons with disabilities the enjoyment or exercise on an equal basis with others of all human rights and fundamental freedoms." Its connection with Article 12 is also underlined by the CRPD Committee: "Non-discrimination includes the right to reasonable accommodation in the exercise of legal capacity. States parties are required to make any necessary modifications or adjustments to allow persons with disabilities to exercise their legal capacity, unless it is a disproportionate or undue burden," (CRPD Committee, 2014, para. 34).
} 
The first is that the legal capacity of persons with disabilities must be primarily tackled from the perspective of those values, principles, and core objectives of the human rights discourse (Cuenca, 2012b: 71ff.). Thus, as the principle of protection had such a prominent role in the traditional system, the value of autonomy becomes particularly important within this new model, i.e. it is key that all persons, including persons with disabilities, be entitled to freely choose their goals, to take the most appropriate steps for the accomplishment thereof, and to make their own mistakes ${ }^{14}$.

Secondly, according to the CRPD, being granted legal capacity is not only a condition to validly perform legal transactions, but is vital to ensure the exercise of all human rights. ${ }^{15}$ In this regard, Article 12 becomes the core of the general paradigm shift fostered by the CRPD regarding the approach to disability: persons with disabilities should be viewed as subjects, as full and active human-rights holders, and not as objects of protection, assistance, and care (Quinn, 2009b: 105).

Within this framework, the first paragraph of Article 12 "reaffirms" that persons with disabilities "have the right to recognition everywhere as persons before the law." According to the opinion of the CRPD Committee, this provision guarantees that a person with disability is respected "as a person possessing legal personality, which is a prerequisite for the recognition of person's legal capacity.” (CRPD Committee, 2014: para. 11). This paragraph may require the review of certain domestic legislation to identify discrimination on the basis of disability; particularly with regards to the effect of the acknowledgement of legal personality (nationality, name, inheritance, documents of identity etc.). Thus, any law or practice that denies persons with disabilities the right to be registered at birth, the right to assume their nationality, the right to inheritance, or the right to obtain an identity document, should be considered contrary to paragraph 1 of Article 12. In any case, Article 12.1 does not protect against the deprivation of legal capacity of persons with disabilities (Bach, 2012: 60).

Paragraph 2 of Article 12 provides that "persons with disabilities enjoy legal capacity on an equal basis with others in all aspects of life." Concerning this provision, it must be clarified that, along the lines of the observations of the CRPD Committee, (2014) "legal capacity includes the capacity to be both a holder of rights and an actor

\footnotetext{
${ }^{14}$ On the adaptation of the human rights-based approach to achieve inclusion of persons with disabilities, see Cuenca, 2015.

${ }^{15}$ In this regard, the CRPD Committee (2014: paras 8 and 31) remarks that "legal capacity is indispensable for the exercise of civil, political, economic, social and cultural rights" and notes that its recognition is inextricably linked "to the enjoyment of many other human rights provided for in the CRPD including, but not limited to, the right to access justice (Art. 13); the right to be free from involuntary detention in a mental health facility and not to be forced to undergo mental health treatment (Art. 14); the right to respect for one's physical and mental integrity (Art. 17); the right to liberty of movement and nationality (Art. 18); the right to choose where and with whom to live (Art. 19); the right to freedom of expression (Art. 21); the right to consent to medical treatment (Art. 25); and the right to vote and stand for election (Art. 29). Without recognition of the person as a person before the law, the ability to assert, exercise and enforce those rights, and many other rights provided for in the Convention, is significantly compromised".
} 
under the law" (thus including both capacity for rights and capacity to act). ${ }^{16}$ Secondly, from the wording of this provision (which provides for no distinctions whatsoever), it can be inferred that Article 12(2) establishes the "universal legal capacity" paradigm for all persons with disabilities with no exclusions on the basis of the kind or degree of disability. ${ }^{17}$ This stems from the need to provide access to the support that persons with disabilities may require, as laid down in Article 12(3), as well as from the open-ended definition of disability enshrined in Article 1 of the CRPD. ${ }^{18}$

Thirdly, it must be recalled that, according to Article 12.2, legal capacity cannot be questioned on the grounds of disability. It is discrimination on the basis of disability, which is expressly forbidden by Article 5 of the CRPD (CRPD Committee, 2014: para. $32)^{19}$. In order to understand the scope of this prohibition it is crucial the distinction between legal capacity and mental capacity. As the CRPD Committee affirms legal capacity - both strands legal standing and legal agency - "is an inherent right accorded to all people, including persons with disabilities", whereas mental capacity refers to the decision-making skills of a person, "which naturally vary from one person to another and may be different for a given person depending on many factors, including environmental and social factors". Under article 12 of the Convention, "perceived or actual deficits in mental capacity must not be used as justification for denying legal capacity” (CRPD Committee, 2014: paras. 13 and 14) ${ }^{20}$

In this vein, as stated by the CRPD Committee (2014, para. 15), granting legal capacity "on an equal basis" excludes the "status approach" that considers that the person's disability or the existence of a given impairment (including physical, sensory, mental, or intellectual impairments) are valid grounds for denying legal capacity. Additionally, this equal recognition of legal capacity also excludes the "outcome

\footnotetext{
${ }^{16}$ One of the most significant debates in the negotiations regarding Article 12 of the CRPD, which almost led to Article 12 being passed with a footnote, was actually about the meaning and scope of the notion of "legal capacity." The drafted footnote stated the following: "In Arabic, Chinese and Russian, the term 'legal capacity' refers to 'legal capacity for rights,' not the 'legal capacity to act.”' In any event, in addition to the General Comment of the CRPD Committee, the Report issued by the Office of the High Commissioner for Human Rights submitted to the Special Committee in their Sixth Meeting entitled "Legal Capacity", 2005 can also support this claim.

17 As highlighted by the CRPD Committee, "the right to equal recognition before the law implies that legal capacity is a universal attribute inherent in all persons by virtue of their humanity and must be upheld for persons with disabilities on an equal basis with others," (CRPD Committee, 2014; para. 8).

${ }_{18}$ According to Article 1 of the CRPD, "Persons with disabilities include those who have long-term physical, mental, intellectual or sensory impairments which in interaction with various barriers may hinder their full and effective participation in society on an equal basis with others.”

19 Article 2 establishes that for the purposes of the CRPD "Discrimination on the basis of disability" means "any distinction, exclusion or restriction on the basis of disability which has the purpose or effect of impairing or nullifying the recognition, enjoyment or exercise, on an equal basis with others, of all human rights and fundamental freedoms in the political, economic, social, cultural, civil or any other field. It includes all forms of discrimination, including denial of reasonable accommodation.”

${ }^{20}$ Article 2 establishes that for the purposes of the CRPD "Discrimination on the basis of disability" means "any distinction, exclusion or restriction on the basis of disability which has the purpose or effect of impairing or nullifying the recognition, enjoyment or exercise, on an equal basis with others, of all human rights and fundamental freedoms in the political, economic, social, cultural, civil or any other field. It includes all forms of discrimination, including denial of reasonable accommodation.”
} 
approach," which takes into consideration the consequences of the decisions made by persons with disabilities, and it will come into play when such decisions were deemed either contrary to their own interests or socially unacceptable. Finally, Article 12 also excludes the "functional approach," based on the individual assessment of a person's mental capacity to make a given decision or enforce a specific right. ${ }^{21}$ As underlined by the CRPD Committee, “in all of those approaches, a person's disability and/or decisionmaking skills are taken as legitimate grounds for denying his or her legal capacity and lowering his or her status as a person before the law. Article 12 does not permit such discriminatory denial of legal capacity” (CRPD Committee, 2014: para. 15). Furthermore, Article 12(2) requires the abrogation of any legal actions that could be applied to prevent the exercise of legal capacity such as interdictions or incapacitations, and any assessments of mental abilities or legal notions such as "unsoundness of mind," that are exclusively applied to persons with disabilities (CRPD Committee, 2014: para. 13 and 15).

This guarantee of equality in the exercise of legal capacity obviously obliges governments to "take appropriate measures to provide access by persons with disabilities to the support they may require in exercising their legal capacity" as stated in Article 12(3). As Flynn and Arstein-Kerslake argue (2014: 81-85) Article 12 of the CRPD "identifies that an individual has a right to legal capacity irrespective of whether or not they have a disability, and simultaneously recognizes that some people require assistance to exercise their legal capacity”.

Accordingly, as mentioned above, Article 12 provides for replacing substituted decision-making regimes with supported decision-making alternatives. ${ }^{22}$ As clarified by the CRPD Committee, a total replacement must take place, inasmuch as "the development of supported decision-making systems in parallel with the maintenance of substitute decision-making regimes is not sufficient to comply with Article 12 of the Convention.” (CRPD Committee, 2014: para. 28).

According to Article 12(4), the support systems in the exercise of legal capacity must incorporate "appropriate and effective safeguards to prevent abuse in accordance with international human rights law." Although such safeguards must be implemented in the adoption of the support system on a national level, the Convention points out several specifics that need to be assured (Palacios, $2008 \mathrm{~b}$ ) notably the need for these support measures to respect the rights, will, and preferences of the person; the need for them to be free of conflicts of interest and undue influence; the need for them to be proportional and tailored to the person's circumstances; and the need for them to be

\footnotetext{
${ }^{21}$ An analysis of these three approaches can be seen in Dhanda, 2006-2007. A source of criticism of the outcome approach, preventing persons with disabilities from making their own mistakes can be seen in Quinn, 2010. The Committee underlines that Article 12 discards the functional approach, inasmuch as certain sectors claim that it would be the approach adopted by the CRPD. Considering Article 12 as a post-functionalist instrument can be seen in Quinn, 2016.

${ }^{22}$ According to the CRPD Committee, 2014, para. 16 "States parties must refrain from denying persons with disabilities their legal capacity and must, rather, provide persons with disabilities access to the support necessary to enable them to make decisions that have legal effect”.
} 
subject to regular review by a competent, independent, and impartial authority or judicial body. The CRPD Committee (2014, para. 20) considers that the primary purpose of these safeguards must be to ensure the respect of the person's rights, will and preferences. In the opinion of the CRPD Committee (2014: para. 21) according to Article 12, the "will and preferences" paradigm must replace the "best interests" paradigm to ensure that persons with disabilities enjoy the right to legal capacity on an equal basis with others. This entails that "where, after significant efforts have been made, it is not practicable to determine the will and preferences of an individual" support measures must focus on abiding by the "best interpretation of will and preferences”.

The CRPD does not design the specific form adopted by the support model. Within the framework of the obligations and safeguards set out in Article 12, each State is free to design its support system taking into account its legal culture and social structure. In any event, in General Comment No. 1, the CRPD Committee, mentions that support may be either formal or informal and stresses the importance of acknowledging its diversity (CRPD Committee, 2014: para. 17 and 18). The General Comment also refers to "certain key provisions" that must be included in the support system (CRPD Committee, 2014: para. 29). Amongst these "key provisions," the following can be highlighted: supported decision-making "must be available to all;" all forms of support in the exercise of legal capacity, including the most intense support measures, "must be based on the will and preferences of the person, not on what is perceived as being in his or her objective best interest;" these forms of support "must be available and accessible and States have an obligation to facilitate the creation of support;" financial resources must not be a barrier to accessing support to enable the exercise of legal capacity," and support in decision-making must not be used as grounds for limiting other fundamental rights of persons with disabilities ${ }^{23}$.

Finally, as pointed out above, Article 12(5) mentions the obligation to ensure that persons with disabilities have access to a series of economic domains: to own or inherit property; to control their own financial affairs; to have equal access to bank loans, mortgages, and other forms of financial credit from which they have been traditionally excluded; and to ensure that persons with disabilities are not arbitrarily deprived of their property. According to the CRPD Committee, the traditional approach "of denying persons with disabilities legal capacity for financial matters must be replaced with support to exercise legal capacity, in accordance with Article 12, paragraph 3” (CRPD Committee, 2014: para. 23).

\section{THE APPROACH TO LEGAL CAPACITY IN QATAR'S LEGAL SYSTEM}

Qatar is an independent sovereign Arab State with a legal system based on a mixture of civil law and Shari'a law. Shari'a law is also recognized in the Qatari Constitution, (Article 1) adopted on June 8, 2004 as the principal source of legislation.

\footnotetext{
${ }^{23}$ On the model of support in decision making see Inclusion Europe, 2008 and Inclusion Internacional 2014. In the academic field see, for example, Gooding, 2013; Flynn and Arstein-Kerslake, 2014b or Booth Glen, 2015.
} 
A modernization strategy, adopted by General Secretariat for Development Planning, Qatar National Vision 2030, is aimed at renewing and developing the country, thereby reinforcing its commitment towards human rights. Therefore, Qatar's presence in the international system of human rights protection is relatively recent and the State is still awaiting the ratification of very relevant instruments. ${ }^{24}$ In any event, as part of its reform strategy, Qatar ratified the CRPD in $2008 .{ }^{25}$ By virtue of this ratification, the CRPD became part of national law in Qatar. Article 6 of the Constitution of the State of Qatar provides that the State shall respect all international charters and conventions to which it is party and strive to implement them all. Qatar completed its initial review process before the CRPD Committee in September 2015 with the adoption of the Concluding Observations on the Initial Report of Qatar ${ }^{26}$ (CRPD Committee, 2015).

As noted by the CRPD Committee, in spite of relative advancements, Qatar still views disability from the perspective of assistencialism and the medical model, far from the human rights-based approach and the social model advanced by the CRPD. ${ }^{27}$ This perspective, enshrined in Qatar's legal system as a whole, and particularly in Law (Act) No. 2 of 2004 on People with Special Needs, ${ }^{28}$ certainly inspires the regulation of legal capacity.

As explained above Arab countries, among others, promoted, during the negotiation of the CRPD, the introduction of a footnote to Article 12.2 limiting the meaning of legal capacity in Arabic, to "capacity of rights," rather than "capacity to act." This proposal was an attempt to make substantive changes to the content of Article 12, disguised as a linguistic issue and it was deleted by the Eight Ad Hoc Committee.

As happens in other countries, Qatari regulation on legal capacity pervades its entire legal system, thus inhibiting the general performance of legal transactions and acts and the exercise of many rights for persons with intellectual and psychosocial disabilities. Since this paper cannot assess all Qatari legal provisions related to legal capacity, this study will focus on analyzing the general framework regarding the recognition of legal capacity and its implications in the specific domain of Private Law.

\footnotetext{
${ }^{24}$ Such as the International Human Rights Covenants of 1966. The Working Group on the Universal Periodic Review shows the intention to ratify these particular covenants in its Report.

${ }^{25}$ However, Qatar did not ratify the Optional Protocol of the CRPD regarding the individual complaints procedure and inquiry procedure.

26 All documents pertaining to this process are available at http://tbinternet.ohchr.org/_layouts/TreatyBodyExternal/SessionsList.aspx?Treaty=CRPD (last accessed January 10, 2017).

${ }^{27}$ See a general analysis on the challenges faced by Qatar in the implementation of the CRPD in De Asís Barranco; Cuenca; Rodríguez del Pozo and Al Ali K., 2017.

${ }^{28}$ In this law, persons with disabilities are defined, from a medical model perspective, as "any person with a permanent total or partial disability in any of the senses or in his or her physical ability or in his or her psychological or mental ability to such an extent that his or her opportunity to learn or to undergo rehabilitation or to earn a living" (Article 1). The perspective of specialty, according to the medical model, is also present in other definitions, such as "Special education," "Rehabilitation," and "Special Education Institutes.”
} 
As evidenced below, the general features of Qatar's legislation on legal capacity are in line with legislation in other countries that still have not implemented Article 12 of the CRPD. In any event, the distinct feature in Qatar that should be taken into account is the influence of Shari'a law in some civil provisions in this field.

\subsection{General framework on legal capacity in Qatar}

In Qatar, legal personality is considered a universal trait, attributed to all human beings in its Civil Code, and there are no restrictions or gradations on the basis of disability. ${ }^{29}$ The initial report submitted by Qatar before the CRPD Committee (2010: para. 138, 139 and 140) states that every disabled child "is registered at birth and given a name and nationality," ${ }^{30}$ and it asserts that these rights shall not be denied or restricted on grounds of disability. ${ }^{31}$ Regarding inheritance, Article 43 of the Code of Family Law $^{32}$ similarly does not make any distinction on the basis of disability. Therefore, Qatari legislation is generally in line with the requirements set out by Article 12(1) of the CRPD.

However, Qatari legislation is rooted in the substitution model with regards to legal capacity. The Civil Code (Article 49) ${ }^{33}$ determines that the recognition of full legal capacity depends upon the individual being of full legal age, reached at the age of 18, and on "mental competence." In this regard, those who are not considered mentally competent may be incapacitated. It can be inferred from certain provisions ${ }^{34}$ that incapacitation in Qatar can be either total or partial, which may be an advantage vis-àvis those legal systems that only provide for total incapacitation.

As laid down in Article 52 of the Civil Code and in Article 190 of the Code of Family Law "persons of no or defective capacity" shall be governed by the provisions of natural or legal guardianship or curatorship as provided for by special laws. The special legal provision governing this matter is Law (Act) No. 40 of 2004 on the Guardianship over Minors' Funds. Article 33 of the said Act is worded as follows: "no person above the age of majority who is subject to a habitual state of madness or insanity, or is unconscious, mentally deranged or an imbecile ... shall be allowed to take charge of his own affairs or to administer his estate." This Law considers "incapacitated" to mean an incompetent minor or an insane, unconscious, or idiotic

\footnotetext{
${ }^{29}$ Law (Act) No. 22 of 2004 Promulgating the Civil Code. As pointed out in Article 39 of the Civil Code "the personality of a human being shall commence upon being born alive and shall cease upon death."

${ }^{30}$ Law (Act) No. 5 of 1982 on Births and Deaths Registration Regulation and Law (Act) No. (38) of 2005 on the acquisition of Qatari Nationality.

31 As explained in Qatar's Initial Report, the Department of Nationality and Travel Documentation allocates a personal (national) number to every newborn child, regardless of whether the child has a disability or not. Persons with disabilities are exempted from paying fees for the issuance and replacement of a Qatari passport and a Qatari identity card (CRPD Committee, 2010: para. 141).

${ }^{32}$ Law (Act) No. 22 of 2006 on Family Law.

33 This provision states that "any person who attains the age of majority and is in possession of his mental faculties shall have full legal capacity to perform legal acts, unless guardianship or custody of his property is decided to be continued or unless such person is incapacitated.”

${ }^{34}$ Articles 49 and 52 of the Civil Code.
} 
person. In its general provisions, the Act defines the meaning of "the insane,"35 "the unconscious," 36 "the idiotic," 37 and "the imbecile" 38 and identifies them as persons with psychosocial or intellectual impairments.

Accordingly, in Qatari legislation, certain impairments are deemed to constitute a lack of the necessary mental capacity required before full legal capacity can be acknowledged. Additionally, pejorative and stigmatizing terms and definitions are used to refer to persons with disabilities that may be deprived of legal capacity. Hence, in accordance with the analysis carried out in the previous section, these provisions are discriminatory and breach Articles 12(2) and 5 of the CRPD.

In Qatar, persons who are incapacitated are subject to a special system of guardianship (Curation or Qawama) pursuant to which a third person is appointed to manage the incapacitated person's property and affairs. Regarding persons who exercise this guardianship, Article 32 of the Law on the Guardianship over Minors' Funds provides that the Qawama "shall be accorded to the major son, then to the father, then to the authority." Furthermore, Article 40 of this law states that any provisions regulating the legal guardianship of a minor shall apply on curation, and the curator shall be bound by such provisions.

Therefore, the legislative framework regarding legal capacity of persons with disabilities in Qatar is based on the adoption of substituted decision-making, and it equates persons with disabilities to minors, which does not comply with the requirements laid down by the CRPD.

Within Qatar's legal system, the process of incapacitation rests with a judicial authority, which amounts to a guarantee in comparison with other domestic legal systems where an administrative decision suffices. Article 33 of the Law on the Guardianship over Minors' Funds clearly asserts that "no interdiction shall be lifted without a court order." Furthermore, Article 118 of the Qatari Civil Code states that "the courts shall interdict a person suffering from insanity, imbecility, inattentiveness or prodigality, in accordance with the rules and procedures prescribed by law." However, Qatar does not seem to have sufficiently detailed regulation specifically governing the incapacitation procedure. In this regard, the rules and regulations in place simply provide that the judge shall verify the person's condition-i.e. that he/she is in a habitual state of madness or insanity, or that he/she is unconscious, mentally deranged, or an imbecile- - "by oral testimony of knowledgeable people or other legitimate means of proof." 39

\footnotetext{
35 The "insane" means any person who is extremely or intermittently foolish, demented, unwise, irrational, or mentally ill.

${ }^{36}$ The "unconscious" means any person who has no awareness because of illness or old age.

37 The "idiotic" means any person who is mentally deranged, muddled, or perverted.

38 The "imbecile" means any person who shows mental feebleness or incapacity.

${ }^{39}$ Article 33, Law on the Guardianship over Minors' Funds.
} 
As in other domestic legal systems, the regulation of incapacitation and the guardianship system in Qatar focuses on property and economic and financial aspects, disregarding personal aspects and the enforcement of fundamental rights, despite the fact that incapacitation in Qatar (as well as in other national legal systems) also has an impact on these spheres.

Regarding safeguards, Qatari legislation does not include references to any obligation to hear the affected person or to take his or her will or preferences into account during the incapacitation procedure; it does not provide any such safeguards either in the choice of the curator or in the application of the system of guardianship. Additionally, it does not provide for any commitment to periodically review the declarations of incapacity nor is there any specific procedure aimed at fostering reintegration or the recovery of the person's legal capacity. In any event, and of further concern, is that in Qatar legal capacity is a prerequisite to becoming a party in judicial proceedings $^{40}$ so incapacitated persons cannot claim the recovery of their legal capacity for themselves.

Nonetheless, in Qatar there are competent authorities to monitor the performance of incapacitated persons' guardians as well as to prevent potential abuses. The General Authority for Minors' Affairs is a government organization that aims to protect the financial rights of minors and individuals with partial or total legal incapacity by safeguarding and investing their money to ensure their well-being. In this vein, this authority is vested with powers to act as the guardian of any incapacitated person who does not have an appointed curator and to monitor curators' activities to ensure that they comply with applicable law. In line with the general framework of incapacitation in Qatar, the duties performed by these authorities mainly focus on economic concerns. Curators, as legal guardians of minors, must submit annual accounts and related documents to the said authority for auditing purposes, as well as to the judge for endorsement purposes. ${ }^{41}$

The Public Prosecutor is also empowered to "investigate, revoke, restrict, halt, or reject custodianship applications, as well as applications for the confirmation and appointment of guardians [...] and other matters relating to incapacitated or incompetent persons." 42

Moreover, pursuant to the provisions governing minors' guardianship, the performance of duties of particular economic significance by the curator requires prior judicial authorization, which must be granted following the relevant opinion of the Authority for Minors’ Affairs. ${ }^{43}$ In addition, there are certain measures in place aimed at preventing potential conflicts of interest. ${ }^{44}$

\footnotetext{
${ }^{40}$ Law 13/1990 Civil and Commercial Procedure Law.

${ }^{41}$ Article 23(5) of the Law on the Guardianship over Minors' Funds.

${ }^{42}$ Article 7 of the Law No. 10 of 2002 on the Public Prosecution.

${ }^{43}$ Hence, as provided by Article 9 of the Law on the Guardianship over Minors' Funds, the natural guardian of a minor, and thus also the curator of an incapacitated person, "may not carry out the following acts without the permission of the court: “ 1 . Disposing of the minor's real estate. 2 . Lending or
} 
Under the abovementioned Qatari legal provisions, curators substitute incapacitated persons when executing many legal transactions, as well as when exercising various rights (including fundamental rights). In this sense, the CRPD Committee expressed its concern "about substituted decision-making and guardianship regimes for persons with disabilities" enshrined in several laws "which restrict the exercise of rights, including the right to vote, to marry, to have a family, to give and/or withdraw free and informed consent, to access justice and choose where and with whom to live” (CRPD Committee, 2015: para. 23).

However, although the general rule in the Qatari legal system is replacement in decision-making processes, there are certain mechanisms that allow some incapacitated persons to manage their assets under certain conditions. Qatar's initial report submitted to the CRPD Committee (2010: para 93) states that some persons "under guardianship may take over the management of all or some of their assets, with the permission of a judge, and after the authority has been consulted.” In this case the provisions on minors who are authorized to handle their own affairs are applicable. Such provisions entail the applicability of the "best interest" standard of protection. According to Article 34 of the Law (Act) on the Guardianship over Minors' Funds, which is mentioned in this point in the report, this provision applies to the "interdicted imbecile" (as well as to prodigal persons). ${ }^{45}$

The Qatari Civil Code also considers (see Articles 119-125) that persons under interdiction for prodigality or for "inattentiveness" may be legally competent to perform certain acts ${ }^{46}$ (including the administration of their property, the conclusion of an employment contract, and the disposal of income obtained from such employment). The

\footnotetext{
borrowing the minor's money. 3. Renting the minor's property for more than one year, or one year after he reaches the age of majority. 4. Accepting or refusing donations subject to conditions. 5. Mortgaging or donating the minor's property. 6. Disposing of the minor's business or securities. 7. Continuing to trade in a business after the minor possession thereof."

${ }^{44}$ Along these lines, Article 18 of the Law on the Guardianship over Minors' Funds provides that "[a] judge may appoint the Authority or other special guardian and define such appointment as follows: 1 . Where the interests of the minor conflict with the interests of the natural, testamentary or legal guardian, or one of his guardians, or his ascendants, descendants or spouse, or with the interests of another minor whom the guardian represents. 2. Where a financial contract concluded between the minor and one of the persons mentioned in the previous paragraph is terminated, revoked or canceled. 3 . Where the minor receives donations and the donor requires that the guardian may not manage the minor's money 4 . Where special knowledge is required to manage some of the minors' businesses. 5. Where the natural, testamentary or legal guardian is ineligible to exercise any guardianship rights.”

${ }^{45}$ However, it is worth noting that Qatar's Initial Report does not literally contain this provision, but rather it refers to persons incapacitated on the grounds of "irresponsibility or ineptitude."

${ }^{46}$ Accordingly, pursuant to the Civil Code, contracts concluded by a person placed under interdiction for prodigality or inattentiveness after the registration of the interdiction application shall be governed by the provisions of Article 111, which governs the disposal of property by minors possessing discretion, so the contracts shall be valid when wholly to their advantage and void when wholly to their disadvantage. If persons under interdiction for prodigality or for "inattentiveness" are authorized to take possession of their property, they are considered competent to manage and administer such property. They are also considered legally competent to enter into an employment contract and dispose of the income from such employment, again within the same limits applicable to discerning minors. And, if duly authorized by a court of law, the disposal of a wakf (endowment) or the execution of a will shall be valid.
} 
limits for the performance of these acts by persons "under interdiction" are the same as those employed in the case of "discerning minors," and they basically entail, yet again, the protection of their "best interest." 47 Insofar as the applicable legislation fails to provide an express definition of the notion of "inattentiveness," it remains unclear to which incapacitated persons with disabilities, if any, these provisions apply.

Although the previous provisions do not meet the requirements laid down in Article 12(2) of the CRPD - since they equate the situation of persons with disabilities under guardianship to the situation of minors and they give priority to the "best interest" standard - they do provide an advantage as a starting point for the implementation of the said provision in comparison with other systems, which do not allow incapacitated persons to make their own decisions in any sphere and by any means.

\subsection{Legal capacity to enter into a contract and to exercise civil rights}

Qatar's civil legislation considers legal capacity to be essential before entering into a valid contract. In this regard, Article 108 of the Civil Code provides that the consent to contract shall be valid only if given by a legally competent person, and Article 109 clarifies that every person who has not been declared by the law to be of total or partial legal incapacity shall have the legal capacity to conclude a contract. ${ }^{48}$ As for incapacitated persons, their legal representatives are empowered to enter into an agreement on their behalf.

At this point, it is worth noting that Qatari legislation provides for a mechanism to assist certain persons with disabilities when concluding a contract. Hence, regarding persons with severe physical and sensory disabilities (particularly deaf and dumb, blind and deaf, or blind and dumb) who "cannot understand the contents or surrounding circumstances of a contract, or cannot effectively communicate their will,” Article 127 of the Civil Code provides for the possibility of appointing "a judicial assistant to assist such person as may be necessary in his/her best interests.” After this appointment, any acts performed by the disabled person without such assistance may be rendered invalid (Article 128). Under certain circumstances when, "due to severe debilitating illness a person cannot conclude a disposal even with judicial assistance, or if the person abstains from doing so," the relevant court of law may allow the judicial assistant to conclude the agreement unilaterally if failing to do so could undermine the person's "best interest."

These provisions establish a support mechanism for the exercise of the capacity to enter into a contract that could extend to other domains where assistance in decision-

\footnotetext{
47 The notion of "discerning minors" means, in accordance with the Law on the Guardianship over Minors' Funds (Article 1): "any person who has attained the age of seven but not the age of majority."

${ }^{48}$ According to Article 120, a contract concluded by a person suffering from insanity or dementia after the registration of the interdiction application shall be null and void. If the contract is concluded before the registration of the interdiction application, it shall not be deemed null and void unless the condition of insanity or dementia was a matter of common knowledge at the time the contract was concluded or if the other party had knowledge thereof.
} 
making is required, and that could also be applied to persons with intellectual or psychosocial disabilities, thereby replacing the long-standing substitution mechanisms. In any case, this assistance should not focus on the criterion of protecting the individual's best interest, but on supporting the expression of, or on interpreting the will and preferences of a person, depending on the specific individual circumstances.

The Civil Code also includes certain provisions aimed at protecting incapacitated persons regarding the results of contractual agreements, ${ }^{49}$ payments that are not legally due ${ }^{50}$ debt payments, ${ }^{51}$ or with regard to the statute of limitations. ${ }^{52}$

Pursuant to Article 939 of the Civil Code, a person without capacity or with deficient capacity may acquire property only through legally-recognized representation.

It is worth noting that, as highlighted by the Report submitted by Qatar to the CRPD Committee, Qatar Central Bank has drafted a number of rules and criteria to guarantee the smooth delivery of banking and financial services to persons with disabilities on an equal basis with others, taking into account their particular circumstances. These rules basically relate to accessibility issues concerning blind persons and persons with reduced mobility (CRPD Committee, 2010: para. 99). The report points out that "concerning support available to persons with disabilities in the realm of exercising their legal capacity and managing their financial affairs, as set out in article 12 of the Convention, the Ministry of Social Affairs has on several occasions followed up with Qatar Central Bank on the subject of a mechanism for enabling persons with disabilities to manage their own financial affairs," (CRPD Committee, 2010: para. 100). However, this mechanism is not specified and whether or not it has been implemented is not addressed.

With respect to civil rights, Article 50 of the Civil Code establishes that "no person who lacks discretion by reason of youth or imbecility or insanity shall be competent to exercise his/her civil rights." Therefore, the key means by which a person's "incompetence" in this domain is determined is not the existence of a legal incapacitation, but rather the "lack of discretion." Once again, considering "imbecility"

\footnotetext{
${ }^{49}$ Article 164 states that "where, however, a contract concluded by a person without legal capacity or with deficient capacity is invalid or annulled by reason of such lack of capacity or deficient capacity, such person shall only be liable to refund any profits he/she obtained from the performance of the contract." General regulation provides that the contracting parties shall be reinstated to the position they were in prior to the conclusion of the contract. Where such reinstatement is impossible, damages equivalent to any loss incurred may be awarded.

${ }^{50}$ Article 222 provides that “[a]ny person who receives payment of any amount not legally due to him/her shall repay such amount. Repayment shall not be required where the person making the payment is fully aware that he is not obliged to make such payment, except where such person is incapacitated or has been coerced into making such payment.”

${ }^{51}$ According to Article 355, payment by an incapacitated person for a given good payable by him/her shall be valid unless the payer suffers any damage due to such payment.

${ }^{52}$ Article 411 states that "[t]he period of prescription shall not apply where a creditor is prevented from claiming his right, even if such prevention is moral; nor shall it apply to the relationship between the principal and his agent. Lack or absence of capacity of the creditor, or a penalty ruled against him, shall be deemed a prevention to claim a right, unless the creditor is legally represented by an agent.”
} 
or "insanity" (designations that are clearly pejorative and stigmatizing as pointed out previously) as decisive factors to determine a "lack of discretion", and therefore the incompetence of a person to exercise his/her civil rights, entails a discrimination in breach of the CRPD.

\subsection{Legal capacity in Family Law}

Although in this paper we do not focus specifically on this issue, it must be noted that, as discussed earlier, many Family Law provisions follow the parameters of Shari'a law. Therefore, there are certain provisions that might be problematic from the perspective of equality for women, and that therefore will also affect women with disabilities. $^{53}$

Within the Family Law domain, being of "sound mind," in some cases alongside other requirements also based on the medical model and sometimes grounded on the disregard model, ${ }^{54}$ is a common criterion to determine an individual's capacity to exercise rights and perform legal transactions. Once again this standard excludes persons with disabilities.

As for marriage, the Code of Family Law requires the "competence" of the intending spouses to consent (Article 12), ${ }^{55}$ and it also requires the "sanity and maturity" of both parties in order for the marriage to be legitimate (Article 14).

Under Qatari legislation, marriage between "mentally ill or incompetent persons" shall not be authenticated save under the following conditions: approval of the guardian, ${ }^{56}$ verification of consent and knowledge of the mental condition by the other party entering into a marriage contract, and verification by a competent medical expert that the illness will not be transmitted to his/her descendants. ${ }^{57}$ Additionally, persons with intellectual or psychosocial disabilities are also subject to restrictions if they wish

\footnotetext{
${ }^{53}$ For instance, appointing a guardian for the bride, considering that only men can act as guardians or witnesses to a marriage, the rights and duties of the intending spouses, the regulation of the abovementioned Curation or Qawama etc.

${ }^{54}$ Within this model, persons with disabilities are deemed unnecessary due to various reasons (because they do not help the community in fulfilling its needs, because they are a burden for their families and society as a whole, because they are evil, or because since their lives are so miserable they are not worth living). Thus, this approach justifies disregarding persons with disabilities: their removal by means of eugenic practices or dooming them to a fate featured by exclusion and marginalization. See Palacios A., El modelo social de discapacidad, pp. 92ff.

${ }_{55}$ According to Article 12, the following conditions shall be required in order for the marriage contract to be valid: 1. Competence of the parties and their being free from legal disabilities. 2. Validity of offer and acceptance. 3. The guardian satisfying conditions in accordance with the provisions of this Law. 4. The witnesses, as stipulated in this Law.

${ }^{56}$ As for every marriage, the bride's guardian must be appointed in accordance with Article 12 of the Code of Family Law cited in the previous footnote. This institution applies pursuant to Shari'a law.

${ }^{57}$ Article 15 of the Code of Family Law
} 
to act as guardians or witnesses to marriage, since in both cases Qatar's legal provisions also require that guardian or witness to be of "sound mind." 58

This criterion also applies to divorces, as laid out in Article 110 of the Code of Family Law. Under this provision, any divorce involving an insane person or a person with an intellectual disability shall have no effect.

It is worth noting that Article 18 of the Code of Family Law provides for compulsory pre-marital examinations for Qataris and non-Qataris: parties must submit to the marriage attestator/notary a medical certificate from a competent medical authority specifying that they are free from genetic and other diseases (listed by the National Health Authority in coordination with the relevant authorities). The marriage attestator/notary shall notify each party of the content of the submitted medical certificate before the signing of the contract, but may not reject the contract's authentication as a result of the medical examination if the parties so desire. ${ }^{59}$ In addition, Qatari legislation provides for separation on grounds of defect or illness. ${ }^{60}$ According to Article 123, "each of the spouses may request separation on grounds of a defect or chronic illness which makes marital life impossible to continue, and for which there is no cure or for which a cure can be hoped for only after a time period of more than one year, whether such illness is mental or physical and whether contracted before or after the marriage contract.”

"Be[ing] of sound mind" and "be[ing] free from dangerous contagious or infectious diseases," (including HIV pursuant to Qatar's legislation) are requirements that must be met in order to be eligible for child custody. ${ }^{61}$ Also, in order to become a minor's legal guardian one must "be sane." 62 Again "be[ing] of sound mind” is required in the proof of parentage by admission. ${ }^{63}$

This regulation is not only contrary to Articles 12 and 5 of the CRPD, it also amounts to a violation of Article 23. This last provision, which is connected with Article 12 of the CRPD (as underlined by the CRPD Committee in its General Comment No. 1) grants persons with disabilities the right to "respect for home and the family.” Compliance with this right requires States Parties to implement effective and appropriate measures to eliminate discrimination against persons with disabilities in all

\footnotetext{
${ }^{58}$ The marriage guardian (Article 26) shall be a male (the father, the agnate grandfather, the son, the full brother, paternal half-brother, the full uncle, and then the paternal uncle, respectively) of sound mind and mature, and not in the state of ritual consecration (Ihram) for Hajj or Umrah, and a Muslim if the guardianship is for a Muslim woman. The witnesses must be two Muslim males who must also be of sound mind and mature and competent, having heard the offer and acceptance and having understood that marriage is intended (Article 36).

${ }^{59}$ In its Report, Qatar states that this examination is aimed at the early identification of certain diseases, in order to ensure a healthy marriage and minimize risks to which spouses may be exposed after their marriage due to a genetic or serious disease (CRPD Committee, 2010: para. 161).

60 Articles $123-127$ of the Code of Family Law.

${ }^{61}$ Article 167 of the Code of Family Law.

${ }^{62}$ Article 4 of the Law (Act) on the Guardianship over Minors' Funds.

${ }^{63}$ Article 89 of the Code of Family Law.
} 
matters relating "to marriage, family, parenthood and relationships, on an equal basis with others." In particular, it requires States Parties to ensure, among other aspects, the right of all persons with disabilities, who are of marriageable age, to marry and start a family on the basis of free and full consent. Finally, States Parties are also required to guarantee the rights and responsibilities of persons with disabilities with regards to guardianship, wardship, and trusteeship of children, or other similar institutions related to minors. With respect to Article 23, the CRPD Committee in its Concluding Observations on the application of the Convention in Qatar expressed its concern "about discriminatory laws and policies that restrict the rights of persons with disabilities, in particularly [sic] women, in all matters relating to marriage, family, parenthood and relationships, on an equal basis with others" ( CRPD Committee, 2015: para. 41).

Regarding the capacity to make a will, Article 214 of the Code of Family Law establishes that the testator must be of sound mind, he/she shall be an adult, and must have legal capacity to gift. However, if the testator is under guardianship for prodigality or inadvertence, his will for benevolence may be validated by permission or approval of the Court. To assess this provision, we need to ascertain the meaning of "persons under guardianship for inadvertence," which, yet again, is not defined in the law. Similarly, a legatee must have the legal capacity to own property. ${ }^{64}$ Article 209 of the Code of Family Law states that the beneficiaries of a legacy must be legally allowed to donate, hence, in accordance with Article 197 of the Code of Family Law, possessing full legal capacity, being an adult, being of sound mind, having free will, not being under guardianship, and not suffering from a terminal illness. As for a person under guardianship, the guardian must accept the will and he/she may not reject it except upon authorization by the Judge. ${ }^{65}$

In spite of the shortcomings of Qatari Family Law in terms of Article 12 of the CRPD, we can identify some strengths from the perspective of persons with disabilities regarding the expression of consent in the context of marriage, divorce, and wills. Regarding marriage, consent must be given in verbal pronouncements, although in case of "inability to speak" the law provides that the intending spouses may "express the understanding of the meanings in writing or any form of acceptable communication." 66 As for divorce, express pronouncement or writing is required but in the case "of inability to pronounce or write," divorce may take effect by understandable gesture. ${ }^{67}$ Similarly, as for wills, one's will can be expressed through understandable gestures (if the testator cannot express himself/herself verbally or in writing). ${ }^{68}$

Although these provisions do not address the possibility of providing support or assistance to persons with disabilities to enable them to express their will and preferences in these contexts, they do constitute a good starting point from which these

\footnotetext{
${ }^{64}$ Article 215 of the Code of Family Law.

65 Article 217 of the Code of Family Law.

${ }^{66}$ Article 13 of the Code of Family Law.

${ }^{67}$ Article 107 of the Code of Family Law.

${ }^{68}$ Article 213 of the Code of Family Law.
} 
support measures along with all accessible communication formats, might be included in future.

\section{Certain NeCEssary CHANGes}

Adapting Qatar's legislation to Article 12 of the CRPD is one of the biggest challenges posed by the CRPD, as happens with almost all States Parties ${ }^{69}$. In order to meet the challenge, several changes have to be implemented.

Firstly, a general paradigm shift must take place regarding the approach of legislation and public policies to disability issues. The assistencialism perspective and the medical model should be abandoned once and for all, and the rights-based approach and social model should be implemented swiftly and resolutely. This entails, among other things, replacing the Law on People with Special Needs with a new piece of legislation expressly banning discrimination on the grounds of disability, as well as acknowledging and guaranteeing accessibility (including the performance of reasonable accommodation) as a pre-condition for the enforcement of all rights, including the right to exercise one's legal capacity on an equal basis.

This new approach must inspire the review of legal capacity legislation "with a view to repealing regimes of substituted decision-making and replacing them by supported decision-making regimes which uphold the autonomy, will and preferences of persons with disabilities," as recommended by the CRPD Committee in its Concluding Observations about Qatar (CRPD Committee, 2015: para. 24). Integral to this replacement must be the requirements set out by the CRPD Committee in its General Comment No. 1, (2014), analyzed in this paper.

This is a very significant and far-reaching regulatory change, which not only affects provisions that lay down the general incapacitation regime and the guardianship system. It also requires a review of all specific provisions that exclude legally incapacitated persons with disabilities from the performance of legal transactions and from the exercise of rights (including human rights), as well as an assessment of all provisions that establish prerequisites related to mental capacity or soundness of mind. Accordingly, the legal capacity of persons with disabilities must be ensured in all areas of life under equal conditions, and access to any assistance that may be required by these persons to exercise their legal capacity must be guaranteed.

Self-evidently, these considerations also affect the specific domain of Private Law, on which we have already focused in this paper. In sum, in this domain, persons with disabilities must be granted legal capacity to enter into a contract and to consent regarding all legal acts, to manage their own economic affairs, to acquire or dispose of property, to exercise their civil rights, to marry, to exercise parental rights and custody and to make a will or to make a donation. The required individualized support mechanisms shall be provided on a case-by-case basis.

\footnotetext{
${ }^{69}$ See some on the major concerns in the implementation of Article 12 CRPD, Gooding, 2015.
} 
This profound legal reform would be very difficult to deliver in the short term, as the experience of other countries shows. However, there are some provisions in Qatari law that allow incapacitated persons to make their own decisions in some spheres and assisted capacity already exists for some specific cases in domestic legislation, which provides a good starting point for the implementation of Article 12. Moreover, until legal reform takes place, the assistance model of Article 127 of the Civil Code (which currently is applied to provide support to persons with severe physical and sensory disabilities when concluding a contract) could be extended to all persons with disabilities (including persons with intellectual and psychosocial disabilities) and to all domains (including not only Private and Family domains but also the performance of acts and the exercise of rights in all the legal spheres) and the "best interest" parameter could be interpreted as relating to respecting the will and preferences of the person with disabilities who needs support in taking decisions. The interpretation of the current regulation in the light of the CRPD could be implemented through different mechanisms according to Qatar's legal and institutional framework while government and stakeholders are working on the necessary legislative reform. ${ }^{70}$

In any case, all these legal changes must be designed and implemented with the participation of persons with disabilities, to the framework of the CRPD. ${ }^{71}$ In order to comply with this obligation, according Qatar should promote, strengthen, and empower associations representing the interests of persons with disabilities. ${ }^{72}$

Nevertheless, an appropriate implementation of Article 12 of the CRPD also requires an urgent social change. In Qatar, as in most of the States Parties of the CRPD, persons with disabilities are perceived by politicians, legal professionals, families, and by society in general as lacking the ability to make their own decisions and exercise their rights on their own. ${ }^{73}$ So, raising awareness of the key players involved in legal reform and of society as a whole is an essential condition to realize the revolution of

\footnotetext{
${ }^{70}$ The obligation of interpreting all relevant national law in a manner that is consistent with the CRDP or other international treaties is implicit in the Article 6 of the Constitution of Qatar, mentioned above, that provides that the State shall respect all international charters and conventions to which it is party and strive to implement them all.

${ }^{71}$ See among others Article 3 of the CRPD, that incorporates as a general principle "Full and effective participation" and Article 4 of the CRPD that includes as a general obligation of the States Parties, the close consultation and the active involvement of persons with disabilities, through their representative organizations, "in the development and implementation of legislation and policies to implement the present Convention, and in other decision-making processes concerning issues relating to persons with disabilities".

${ }^{72}$ The CRPD Committee pointed out that in the past there was a lack of consultation with both individuals with disabilities and with independent organizations regarding disability-related policies and the process of implementation of the CRPD (CRPD Committee, 2015: para. 9). The Qatari National Human Rights Committee (NHRC, 2015 and 2014) has remarked on the lack of a sufficient number of civil society organizations that are concerned with disability issues and the non-existence of specialized associations for certain types of mental disabilities.

73 The shortcomings in the domain of awareness-raising were remarked upon by the CRPD, 2015: para. 17. In particular, the CRPD Committee, 2015: para. 25 is also concerned that judicial officials are unaware of the rights of persons with disabilities.
} 
Article 12, promoting the autonomy of persons with disabilities and enabling them to be the main architects of their own future.

\section{REFERENCES}

ARNSTEIN-KERSLALE, A. and FLYNN, E., (2016). "The General Comment on Article 12 of the Convention on the Rights of Persons with Disabilities: a roadmap for equality before the law”, The International Journal of Human Righs, vol. 20, Issue 4, pp. 471-490.

BACH, M., (2012). "El derecho a la capacidad jurídica en la Convención de la ONU, sobre los Derechos de las Personas con discapacidad”. Available at http://archivo.eluniversal.com.mx/graficos/pdf14/Bach\%20\%20Capacidad_Juridica.pdf (last accessed January 4, 2017).

BARIFFI, F., (2009). "Capacidad jurídica y capacidad de obrar de las personas con discapacidad a la luz de la Convención de la ONU”, L. PÉREZ BUENO, dir., Hacia un Derecho de la Discapacidad. Pamplona, Thomson Reuters Aranzadi.

BARNES, C. \& MERCER, G., (2003). Disability, Cambridge, Polity Press.

BOOTH GLEN, K., (2015). “Supported Decision-Making and the Human Right of Legal Capacity”, Inclusion, vol. 3, n⿳⺈, pp. 2-16. https://doi.org/10.1352/2326-6988-3.1.2

COMMITTEE ON THE RIGHTS OF PERSONS WITH DISABILITIES (2010), Initial Reports of States Parties: Qatar, CRDP/C/QAT/1, Available at http://daccessods.un.org/access.nsf/Get?Open\&DS=CRPD/C/QAT/1\&Lang=E (last accessed May 17, 2017).

COMMITTEE ON THE RIGHTS OF PERSONS WITH DISABILITIES (2014), General Comment No. 1 on Article 12: Equal Recognition before the Law, CRPD/C/11/4. Available at https://documents-ddsny.un.org/doc/UNDOC/GEN/G14/031/20/PDF/G1403120.pdf?OpenElement (last accessed on November 6, 2016).

COMMITTEE ON THE RIGHTS OF PERSONS WITH DISABILITIES (2015), Concluding Observations on Qatar, CRPD/C/QAT/CO/1. Available at https://documents-dds

ny.un.org/doc/UNDOC/GEN/G15/226/74/PDF/G1522674.pdf?OpenElement (last accessed on May 6, 2017)

CUENCA GÓMEZ, P., (2011), “La capacidad jurídica de las personas con discapacidad: El Art. 12 de la Convención de la ONU y su impacto en el Ordenamiento jurídico español”, Derechos y libertades, nº 24, pp. 221-257.

CUENCA GÓMEZ, P., (2012a). Los derechos fundamentales de las personas con discapacidad. Un análisis a la luz de la Convención de la ONU. Madrid: Servicio de Publicaciones de la Universidad de Alcalá-Defensor del Pueblo. 
CUENCA GÓMEZ, P., (2012b). "El sistema de apoyo en la toma de decisiones desde la Convención Internacional sobre los Derechos de las Personas con Discapacidad: principios generales, aspectos centrales e implementación en la legislación española”, REDUR, nº10, pp. 61-94.

CUENCA GÓMEZ, P., (2015). “Human Rights and disability: a theoretical analysis”. The Age of Human Rights Journal, n 4, pp. 34-59.

DE BHAILÍS, C. and FLYNN, E., (2017). "Recognising legal capacity: commentary and analysis of Article 12 CRPD”, International Journal of Law in Context, issue 1 , pp. 6-21. https://doi.org/10.1017/S174455231600046X

DE ASÍS ROIG, R., (2013). Sobre discapacidad y derechos, Madrid, Dykinson.

DE ASÍS ROIG, R., BARRANCO AVILÉS, M., CUENCA GÓMEZ, P., RODRÍGUEZ DEL POZO, P. \& AL ALI, K. (2017). "The Impact of the International Convention on the Rights of Persons with Disabilities on Qatari Domestic Legislation”, The Age of Human Rights Journal, nº, pp. 1-17. https://doi.org/10.17561/tahrj.n8.1

DHANDA, A., (2003-2004), Advocacy Note on Legal Capacity, World Network of Users and Survivors of Psychiatry. Available at http://www.un.org/esa/socdev/enable/rights/art9legal.htm (last accessed January 4, 2017).

DHANDA, A., (2006-2007). “Legal Capacity in the Disability Rights Convention: Stranglehold of the Past of Lodestar for the Future?, Syracuse Journal of International Law and Commerce, vol. 34(2), pp. 438-456.

FLYNN, E. and ARNSTEIN-KERSLALE, A., (2014a) "Legislating Personhood: Realising the Right to Support in Exercising Legal Capacity’”, International Journal of Law in Context, vol. 10, pp. 81-104.

FLYNN E. and ARSTEIN-KERSLAKE A., (2014b) 'The Support Model of Capacity: Fact, Fiction or Fantasy?’, Berkeley Journal of International Law, vol. 32(1), pp. 124-143. https://doi.org/10.1017/S1744552313000384

GENERAL SECRETARIAT FOR DEVELOPMENT PLANNING, Qatar National Vision 2030, Available at http://www.mdps.gov.qa/en/qnv/Documents/QNV2030_English_v2.pdf （last accessed March 29, 2017).

GOODING, P., (2013) 'Supported Decision-Making: A Rights-Based Disability Concept and Its Implications for Mental Health Law', Psychiatry, Psychology and Law, vol. 20(3): 431-451. https://doi.org/10.1080/13218719.2012.711683

GOODING, P., (2015) 'Navigating the "Flashing Amber Lights” of the Right to Legal Capacity in the United Nations Convention on the Rights of Persons with 
Disabilities: Responding to Major Concerns', Human Rights Law Review, vol. 15(1), pp. 45-71. https://doi.org/10.1093/hrlr/ngu045

INTERNATIONAL DISABILITY ALLIANCE (2008), Legal Opinion on Article 12 of CRPD. Available at http://www.internationaldisabilityalliance.org/es/node/208 (last accessed January 4, 2017).

INCLUSION INTERNATIONAL. (2014). Independent but not alone: A global report on the right to decide. Available at http://inclusion-international.org/wpcontent/uploads/2014/06/Independent-But-Not-Alone.pdf ((last accessed November 15, 2017).

MINKOWITZ, T. (2006-2007). "The United Nations Convention on the Rights of Persons with Disabilities and the Right to be free from non-consensual psychiatric interventions", Syracuse Journal of International Law and Commerce, vol. 34(2), pp. 405-428.

OFFICE OF THE HIGH COMMISSIONER FOR HUMAN RIGHTS (2005). Report submitted to the Special Committee in their Sixth Meeting, "Legal Capacity". Available at http://www.un.org/esa/socdev/enable/rights/ahc6documents.htm (last accessed January 10, 2017).

NATIONAL HUMAN RIGHTS COMMITTEE (NHRC) (2014). Report of the National Human Rights Committee (NHRC) on the Situation of Human Rights in the State of Qatar and the Committee's Activities during the Year 2014, Available at http://www.nhrc-qa.org/wp-content/uploads/2014/01/en_2014-NHRCreport_finalss2.pdf (last accessed January 3, 2017).

NATIONAL HUMAN RIGHTS COMMITTEE (NHRC) (2015). Annual Report of the National Human Rights Committee on the Situation of Human Rights in the State of Qatar, p. 75 Available at https://www.nhrc-qa.org/wpcontent/uploads/2014/01/93621-National-Human-Rights-English.pdf (last accessed January 3, 2017)

OLIVER, M. (1996). Understanding Disability. From theory to practice, Malaysia, Palgrave. https://doi.org/10.1007/978-1-349-24269-6

PALACIOS, A. (2008a). El modelo social de discapacidad: orígenes, caracterización y plasmación en la Convención Internacional sobre los Derechos de las Personas con Discapacidad, Madrid, Cinca.

PALACIOS, A. (2008b). Consultative Meeting with Stakeholders on Legal Measures Key for the Ratification and Effective Implementation of the CRPD. Conference delivered in the context of the Open-ended Consultation on Key Legal Measures for the Ratification and Implementation of the Convention on the Rights of Persons with Disabilities, performed by the Office of the High Commissioner for Human Rights, Geneva. Available at http://www2.ohchr.org/english/issues/disability/docs/FinalConsultationreport.do c last accessed 4 January 2017). 
QUINN, G. (2009a). An Ideas Paper. Brussels: European Foundation Centre. Available at: http://www.inclusionireland.ie/sites/default/files/attach/basicpage/846/anideaspaperbygerardquinnjune2009.pdf (last accessed January 4, 2017).

QUINN, G. (2009b). "A Short Guide to the United Nations Convention on the Rights of Persons with Disabilities”, G. QUINN \& L. WADDINGTON, eds., European Yearbook of Disability Law: Volume 1. Antwerp: Intersentia.

QUINN, G., (2010). Personhood \& Legal Capacity. Perspectives on the Paradigm Shift of Article 12 CRPD", Harvard Law School. Available at http://www.nuigalway.ie/cdlp/documents/publications/Harvard\%20Legal\%20Ca pacity\%20gq\%20draft\%202.doc. (last accessed January 4, 2017).

QUINN, G. (2011). Rethinking Personhood: New Directions in Legal Capacity Law \& Policy or How to Put the 'Shift' back into 'Paradigm Shift', University of British Columbia, Available at: https://www.inclusionireland.ie/sites/default/files/attach/basicpage/846/rethinkingpersonhood-newdirectionsinlegalcapacitylawandpolicygerardquinn-april2011.docx (last accessed January 4, 2017).

QUINN, G. (2016). From Object to Subject. Reflections on Personhood \& Disability in the 21st Century, Sofia, AJUPID Final Conference. 